\title{
Scepticism in Early Modern Times
}

\section{Introduction}

Anyone interested in defining the nature and function of scepticism in early modern thought cannot overlook the remarkable and always useful work of Richard Popkin on the subject. By emphasising the decisive importance of scepticism in understanding the complexity of early modern thought, his History of Scepticism from Savonarola to Bayle has modified our view about the early modern history of ideas, which cannot be reduced to a simple philosophical variation on Cartesian rationalism. That being said, it seems to me that Popkin's History of Scepticism has provided a somewhat truncated reading of early modern scepticism, for example (1) by exaggerating the sceptical orientation of some of the thinkers he has considered, as we will see later with the example of Pierre-Daniel Huet; (2) by insisting on the influence of Pyrrhonian scepticism at the expense of Academic scepticism; ${ }^{1}$ and (3) by dogmatically denying the existence of a scepticism proper to the Enlightenment (aside from Hume, of course), even though he subsequently modified some of his positions. ${ }^{2}$

In order to propose a specific and critical reading of Popkin's interpretation of the nature and function of early modern scepticism, I will present three figures of that period analysed by Popkin, namely those of Pierre-Daniel Huet, Simon Foucher, and Jacques-Pierre Brissot de Warville. In doing so, I want also to underline the difficulty in presenting a coherent and consistent history of early modern scepticism and the importance of determining precisely the role and function of scepticism at that time, where it is more of an individual attitude than a shared legacy or "school" (as it was in the ancient period), which raises of course the question of its interpretation. This individual attitude varies according to the historical and philosophical context in which it occurred. Indeed, scepticism could not be used in identical ways in, for example, the pre-Cartesian and post-Cartesian contexts; for Cartesian rationalism, in claiming to surmount doubt and achieve certainty by means of the cogito, had required a reconfiguring of the sceptical toolkit, a fact that gave rise to the emergence of a new sceptical typology aimed at opposing this new dogmatism. Similarly, scepticism was obliged to reconceptualise itself in response to the success of Newtonian physics, and this may account for the difference between the radical

\footnotetext{
1 This is a common criticism, particularly in the work of French scholars working on Early Modern scepticism. A good summary of such criticism can be found in Sylvia Giocanti, "Histoire du fidéisme, histoire du scepticisme,” Revue de Synthèse 199, nos. 2-3 (April 1998): 193-210.

2 See my "Introduction: What is Enlightenment Scepticism? A Critical Rereading of Richard Popkin," in Scepticism in the Eighteenth Century: Enlightenment, Lumières, Aufklarüng, eds. Sébastien Charles and Plinio Junqueira Smith (Dordrecht: Springer, 2013), 1-15.
} 
scepticism more characteristic of the seventeenth century-at a moment where all fields of knowledge were being criticised and all forms of dogmatism were a target -and the mitigated scepticism, limited in its spheres of application, of the Enlightenment.

At this level, the analysis I propose contrasts sharply with the usual attacks against Popkin's History of Scepticism. Indeed, what is generally faulted in Popkin is the excessive importance he attributes to the religious question, using Pyrrhonism first and foremost as a critical tool in the service of atheism, ${ }^{3}$ and the relatively vague definition of Pyrrhonism he proposes, which takes little account of the textual tradition in which the sceptical texts are inscribed in order to stress its argumentative dimension. ${ }^{4}$ So in considering the three examples I have just mentioned, the purpose of this work is not so much to criticise Popkin's analysis as to try to demonstrate how difficult it is to speak univocally about early modern scepticism stricto sensus, that is to say in the form of a relatively fixed and consistent method as found in Sextus Empiricus. Rather than rejecting Popkin's general reading of modern scepticism, I prefer to show, by using some striking examples, how the exclusive reduction of scepticism to Pyrrhonism does not work, and represents an important interpretative mistake, similar to a form of reductionism. On the contrary, it is important to understand how any form of reductionism on this topic is unthinkable, because it is impossible to present early modern scepticism as a philosophical stream with internal coherence and a unique purpose.

\section{The Nature and Function of Pierre-Daniel Huet's Scepticism}

Let me begin with the figure of Pierre-Daniel Huet, who is regarded by Popkin as an exemplary representative of "Christian Pyrrhonism," Huet being in fact a "complete Pyrrhonian sceptic." 5 That Popkin adopted this reading of Huet is no surprise, since his general approach concerning scepticism consisted chiefly of emphasising the moderns' rediscovery of ancient Pyrrhonism, even if this meant obscuring or forgetting the other strands of scepticism such as Academic thought in the Classical period. This somewhat biased interpretation is currently being counterbalanced by much more charitable readings of the influence of Academic scepticism on seventeenth and eighteenth century philosophy. For example, Thomas Lennon and José Raimun-

3 Giocanti, "Histoire du fidéisme, histoire du scepticisme.”

4 Emmanuel Naya, "Le phénomène pyrrhonien: lire le scepticisme au XVI ${ }^{\mathrm{e}}$ siècle” (PhD diss., Université Stendhal-Grenoble III, 2000), 5-10.

5 Richard Popkin, The History of Scepticism from Savonarola to Bayle (Oxford: Oxford University Press, 2003), 278-82. 
do Maia Neto ${ }^{6}$ treat today Pierre-Daniel Huet as a central figure in the revival of Academic scepticism. ${ }^{7}$ It is true that a reading of Huet's work soon makes it clear that he was deeply familiar with the sceptical tradition, Pyrrhonian and Academic. ${ }^{8}$ He cites in turn Diogenes Laertius, Sextus Empiricus, Cicero, Aulus Gellius, and Saint Augustine, in support of his arguments, and in so doing he displays a subtle and precise intimacy with ancient scepticism. But if Huet advances an informed reading and a comparatively fair interpretation of the themes and proponents of scepticism, it remains to be demonstrated that he really is a sceptic, and what role he assigns to scepticism within his own philosophical enterprise. In this sense, it is as useless to present Huet as a Pyrrhonian (Popkin) or as an Academician (Lennon and Maia Neto), the stakes of the debate being more consequential than a characterisation which seems as anachronistic as it is sterile. And, in fact, a closer look at his Censure de la philosophie cartésienne quickly reveals that scepticism serves him above all as a weapon against the modern dogmatism represented by Cartesianism. In that sense, the differences between Pyrrhonism and Academism are not really important to him, and he largely prefers to underline their proximity by showing that sceptics have in fact a very similar vision of the real nature of philosophy. ${ }^{9}$ Thus, if he takes the differences between Pyrrhonians and Academic sceptics to be essentially verbal after all, it is because he thinks that they agree to suspend judgment in the realm of theory while following appearances in the realm of practice. In this respect, they are the only true philosophers, for unlike the dogmatics, they seek to attain wisdom and truth rather than claiming to have already achieved them.

In that sense, Huet's recourse to both Pyrrhonian and Academic arguments serves to show how Descartes and his disciples had warped the very essence of philosophy, which consists of doubting and of questioning one's own prejudices. This the Cartesians had done by exceeding the limits imposed by the exercise of doubt and claiming that it is possible for certainty to be borne out of uncertainty by means of the cogito, which is, according to Huet, "a principle that is no less uncertain

\footnotetext{
6 Thomas Lennon, "The Skepticism of Huet's Traité philosophique de la foiblesse de l'esprit humain," in Scepticisme et modernité, eds. Marc-André Bernier and Sébastien Charles (Saint-Étienne: Publications de l'Université de Saint-Étienne, 2005): 65-75; José Raimundo Maia Neto, "Huet n'est pas un sceptique chrétien," Les Etudes philosophiques 2 (2008): 209-22. See also Maia Neto, “Academic Skepticism in Early Modern Philosophy," Journal of the History of Ideas 58, no. 2 (1997): 199-220, and Maia Neto, "Huet sceptique cartésien," Philosophiques 35, no. 1 (2008): 223-39.

7 See Sébastien Charles, "Pierre-Daniel Huet’s Readings in Scepticism," in Academic Scepticism in the Development of Early Modern Philosophy, eds. Plinio Junqueira Smith and Sébastien Charles (Dordrecht: Springer, 2017), 259-74.

8 On this topic, see the sections "La ripresa dello scetticismo antico" and "Huet e la tradizione scettica," in Elena Rapetti, Pierre-Daniel Huet: erudizione, filosofia, apologetica (Milan: Vita e Pensiero, 1999), 255-79.

9 Pierre-Daniel Huet, Traité philosophique de la faiblesse de l'esprit humain (Amsterdam: Henri du Sauzet, 1723), 138.
} 
than all the others that he subjected to doubt."10 In Huet's strategy, sceptical arguments serve to show that it is impossible to treat the cogito as a certain proposition. Hence he accumulates arguments that show that the cogito, which Descartes presents as an intuition, is in fact a deduction, and an invalid one. ${ }^{11}$ This is the central concern of both his Censure de la philosophie cartésienne and his Censure de la réponse de Monsieur Régis à la Censure de la philosophie cartésienne, an incomplete manuscript that Huet intended as a response to a book by Pierre-Sylvain Régis defending Descartes' philosophy.

In fact, for Huet, nothing is less self-evident than the purported self-evidence of the cogito. First, Descartes does not even raise the question of knowing what this term "to be" means and whether the thinking subject really is-a question he ought to have broached if his doubt were as radical as he claimed and extended so far as the category of existence. For after all, as Montaigne had already recognised, the predication of existence should apply in reality only to a single subject, God, the sole truly existent being, since all other natural beings have only a phenomenal, not a substantial, existence. Next, had Descartes examined the question of what being is more thoroughly, he would have recognised that the "I" or the "self" that thinks cannot think without being, and hence that the cogito is nothing more than a tautology: "I am a thinker, therefore I am"; indeed, it is a defective syllogism of the question-begging kind: "If I think, I am; I am; therefore I am." If we look upon the cogito as a line of argument, Huet suggests, we must acknowledge that it is not valid. The major premise that deals with thought is also problematic, for what can it mean if not, "I think that I have thought," since there is both a logical and a chronological anteriority between the moment when we think and the following moment when we have deduced that we exist? Given that Descartes himself recognised that memory is a deceptive faculty, I cannot be sure of having truly thought before concluding that I have true existence, because there is nothing to assure me that this idea of having thought is certain-hence the impossibility of reaching a valid conclusion. Huet presents this line of thought as follows:

La mémoire de l'homme étant peu ferme et peu fidèle, la conclusion peut fort bien s'appliquer à une autre proposition qu'à celle d'où elle est tirée. Ce qui nous arrive tous les jours dans les entretiens familiers, où l'on oublie souvent en raisonnant le sujet de la conversation, et ce qu'on a dessein de prouver. Il n'y a donc rien de certain et il peut y avoir de l'erreur dans la connexion de l'argument de Descartes, et par conséquent il ne vaut rien. Ajoutons à cela que ce raisonnement étant fondé sur ce principe, que tout ce qui pense est au moment qu'il pense, il s'ensuit

10 Pierre-Daniel Huet, Against Cartesian Philosophy, ed. and trans. Thomas M. Lennon (Amherst, New York: Humanity Books, 2003), 1.14.109-10.

11 For an analysis of Huet's critique of the evidence of the cogito, see Sébastien Charles, "Évidence, vraisemblance et vérité selon Huet : le cartésianisme en question," in Les usages de la preuve d'Henri Estienne à Jeremy Bentham, eds. Jean-Pierre Schandeler and Nathalie Vienne-Guerrin (Paris: Hermann, 2014): 101-17; Charles, "On the Uses of Scepticism against a Certain Philosophical Arrogance: Huet as a Critic of Cartesian Logic and Metaphysics," Science et Esprit 65, no. 3 (2013): 299-309. 
que quand je conclus que je suis de ce que je pense, je ne veux rien dire autre chose sinon que je suis dans le moment où je pense. Or, est-il que cette pensée s'évanouit et ne subsiste plus dès que je dis «Donc je suis», puisqu'il y a une différence de temps entre la première proposition et la conséquence ? C'est pourquoi ce raisonnement doit nécessairement signifier ou «Je pense, donc je serai» ou «J'ai pensé, donc je suis». Et, ainsi, cet axiome «Tout ce qui pense est dans le moment qu'il pense», d'où Descartes fait dépendre toute la force de son argument, n'y aura aucun rapport, et pour lui donner quelque force, il faudra le tourner ainsi : «Tout ce qui pense est, même quand il ne pense point». Autant de changements et de corrections qui produiront un sens entièrement faux et ridicule, de l'aveu même de Descartes. ${ }^{12}$

In short, there is no criterion of truth on which we can found a philosophical system in an assured manner. If the arguments against the cogito are not all demonstrative or original, what matters to Huet is to show that deductive propositions purportedly founded on reason are all subject to doubt, based on the fact that reason is a limited and fallible faculty. In that case, scepticism has a protreptic function, but it does not mean that Huet is a sceptic. In fact, Huet's recourse to scepticism is incomprehensible without taking the theological dimension of his thought into consideration. Indeed, scepticism is in no way an end in itself for Huet; it is a strategic means of rejecting Cartesianism because it tends towards conceptualising a unique kind of truth, placing faith and reason on the same level. The Preface to Huet's Censura leaves no room for doubt about his apologetic intentions, which are to criticise Descartes above all, because "although he teaches that philosophy should submit to faith, he in fact adjusted the faith to the principles of his philosophy," 13 thereby opening the door to a subjection of religious truth to reason and allowing the mysteries of faith to be interpreted by reason and rejected on the basis of their implausibility, with, as a consequence, a negation of Christian revelation. On the contrary, Huet thinks that the truths of reason must be subordinate to those of faith and that the exercise of reason

12 Pierre-Daniel Huet, Censure de la philosophie de Descartes, Bibliothèque Nationale de France, manuscript fonds français 14702, 6v-7r. English translation in Huet, Against Cartesian Philosophy, 8889:

Moreover, since man's memory is weak and unstable, the conclusion can be referred to some premise other than the one from which it follows. Something like this happens to us in everyday ordinary discourse, in which it is customary for us not to remember what the subject is of the conversation and what one is trying to prove. Therefore, the connection of this pair of propositions, «I am thinking,» and «I am,» is uncertain and deceitful, and is therefore an invalid argument. To this it may be added that since the argument, «I am thinking, therefore I am,» depends on the proposition, «whatever is thinking, is so long as it thinks,» it follows that when I conclude that I am from the fact that I am thinking, nothing else is meant but that I am so long as I am thinking. And that thought has already ceased when I say, «I am.» The antecedent, «I am thinking,» is at a different time from the conclusion, «therefore I am.» The argument therefore means either «I am thinking, therefore I will be,» or else «I thought, therefore I am.» And the proposition, «whatever is thinking, is so long as it is thinking,» on which Descartes would base his argument, is irrelevant to it. The result is that for it to be useful to his argument, it must be changed to the following, «whatever is thinking is, even while it is not thinking.» Even according to Descartes, these changes and alterations are ridiculous and false. 13 Huet, Against Cartesian Philosophy, 64. 
has to be limited: "I believe that God is three in one, not by virtue of reason, but by virtue of the first truth that revealed this." ${ }^{14}$ In this respect, asking the question whether Huet was truly a Pyrrhonian (Popkin) or an Academic sceptic (Lennon and Maia Neto), or more one than the other, is not of great importance. He is above all a Christian philosopher who uses scepticism in a purely strategic way to serve his apologetic project, which is to preserve Christian religion from the attack of early modern rationalism.

\section{Simon Foucher's Academic Scepticism, or the Sceptical Way to Modern Science}

The interpretation of the second figure, Simon Foucher, is more problematic considering my presentation of Popkin as having little interest in the renewal of Academic scepticism. Foucher presents himself as a modern representative of this philosophical current, and Popkin was of course aware of it, as he quoted it in his History of Scepticism: "Foucher saw himself as the reviver of Academic scepticism."15 Nevertheless, it is not Foucher's interpretation of Academic philosophy that interests Popkin, but his anti-Cartesian epistemology and in particular his critique of the possible distinction between primary and secondary qualities. Surprising as it may sound, the way Foucher interpreted Academic scepticism in the seventeenth century did not interest Popkin, reflecting his disinterest in the question of the modern revival of Academic scepticism.

However, this question is far from trivial. Even if Foucher's interpretation of Academic scepticism is sometimes confusing, it nevertheless enables us to understand what the role of scepticism in early modern thought could be and why it was, according to Foucher, the best and perhaps the only philosophy for his times. ${ }^{16}$ In that case, it is a juste milieu between dogmatism and Pyrrhonism, which is a useful position to legitimatise the scientific spirit of his century: "On peut distinguer les Académiciens des Pyrrhoniens, en ce que les Académiciens reçoivent quelques vérités, comme de géométrie et de mécanique."17 If Foucher wished to rehabilitate Academic philosophy, this was because he saw significant advantages in it. Indeed, Academism ap-

14 Pierre-Daniel Huet, Alnetanae quaestiones de concordia rationis et fidei (Caen: J. Cavelier, 1690), 1.2, §7, 30.

15 Popkin, History of Scepticism, 275.

16 Joël Boudreault and Sébastien Charles, "Simon Foucher’s Academic Scepticism: Between Truth and Probability," in Academic Scepticism in the Development of Early Modern Philosophy, eds. Plinio Junqueira Smith and Sébastien Charles (Dordrecht: Springer, 2017), 245-58.

17 Foucher Simon, Dissertation sur la recherche de la vérité (Paris, Estienne Michallet, 1687), 29-30. English translation: "The Academicians can be distinguished from the Pyrrhonians, in that sense that the Academicians receive some truths, such as in the domains of geometry and mechanics.” All English translations of Foucher are my own. 
peared to be the only philosophy capable not only of dismantling the impasses created by Cartesianism (by making a more useful use of doubt, for example), but also of achieving reconciliation with Christianity, all the while providing the nascent sciences of the time with more flexible, less dogmatic foundations than those advocated by the Cartesians. ${ }^{18}$

Because Foucher thought that a peculiar use of scepticism could support Christianity, assuming a close proximity to Huet's position, as Popkin does, may be understandable, but actually amounts to a significant misinterpretation. Foucher has a much more charitable conception of philosophy than Huet, he stresses its pars construens rather than his pars destruens, and every philosopher who seeks truth with sincerity is on the right path, as long as he knows how to recognise the evidence where it manifests itself, and to remain doubtful when there is no evidence. In fact, it is important to escape either to positive dogmatism (Cartesianism) or negative dogmatism (which is symbolised, for him, by Pyrrhonism, a philosophical current which rejects all type of truths ${ }^{19}$ ). Furthermore, according to Foucher, this is really the method of the Academics:

Il est vrai que les Académiciens doivent douter d'une très grande quantité de choses, mais c'est parce que ces choses sont douteuses, et il se trouve néanmoins que les principales vérités leur sont connues, de sorte que leurs doutes regardent seulement les matières de sciences et les propositions dogmatiques que l'on pourrait faire sur les sujets de pure spéculation humaine. ${ }^{20}$

Another fundamental difference between Foucher and Huet concerns their relation to Cartesianism. Indeed, Foucher's conception of the Academic method of philosophising is strongly influenced by his reading of Descartes, particularly his Discours

18 It should not be forgotten that Foucher prided himself on his own knowledge of science and that he was the author of a study on hygrometers in which he touted the methodological advances of science in his era. See his Nouvelle façon d'hygromètres (N.p., 1672), reissued in his Traité des hygromètres, ou machines pour mesurer la sécheresse et l'humidité de l'air (Paris: Estienne Michallet, 1686). 19 Foucher often tends to present Pyrrhonism as a form of negative dogmatism. This strategy aims to highlight the positivity of academic scepticism. But he tries sometimes to bring them closer, by insisting on their zetetic method: "Les pyrrhoniens et sceptiques différaient de nos académiciens en ce qu'ils ne reconnaissaient aucune vérité, au lieu que nos philosophes en reconnaissent plusieurs. Mais en cela leur différence n'était pas si forte qu'elle ne se pût ôter avec le temps, car les uns et les autres faisaient profession de rechercher la vérité." Foucher, Dissertations sur la recherche de la vérité (Paris: Jean Anisson, 1693), 177. English translation: "The Pyrrhonians or Sceptics differed from our Academicians, in that they did not recognise any truth, instead of our academic philosophers recognize several. In this, their difference was not so strong that it could not be taken away with time, for both professed to seek the truth."

20 Foucher, Dissertation, IX. English translation: "It is true that the Academics must doubt a very large number of things, but that is because these things are doubtful; and it is nevertheless the case that the principal truths are known to them, such that their doubts relate only to the subject matters of the sciences and the dogmatic propositions that could be formulated on topics of pure human speculation.” 
de la méthode. Hence it is no coincidence that some maxims of this method resemble those of Descartes, as, for example, the first one, which consists of refusing to treat the senses as the criterion of truth, and the second one, which requires us to set aside opinions and prejudice. Due to this method, it is possible to demonstrate a number of metaphysical truths that have the advantage of being certain because they are not based on sense perception but on the work of the mind upon itself. ${ }^{21}$ These truths, supposedly all known to the Academics and transmitted esoterically, recall in part the results Descartes arrived at in his Meditations. They consist first (1) of the immediate and primary knowledge of the soul; then (2) of the knowledge of its fundamental characteristics, namely its unity, spirituality, and immortality; (3) then of the knowledge of God and God's essential attributes, namely unity, infinity, and eternity; and last comes (4) the reconciliation of divine providence with human freedom. These truths emerge from demonstrations that are based solely on the work of the mind on itself, which has caused them to follow from one to another and, according to Foucher, transforms Academic philosophy into a kind of praeparatio evangelica, ${ }^{22}$ and Cartesianism into a modern form of Academism. As we can see once more, we cannot embrace a uniform reading of the modern reception of scepticism without questioning the use made of sceptical texts by early modern authors who resort to them. In the specific case of Foucher, the recourse to Academic scepticism leads him to adopt a purified form of Cartesianism, in which its overly dogmatic aspects have been rejected because they tended to lead to an opposition between philosophy and theology.

If Foucher's interpretation of Academic philosophy seems somewhat disconcerting and hardly "sceptical," this has to do with his inclination to stress the epistemological productivity of this method to defeat Cartesianism on its own ground, even if he shares with Descartes more or less the same conception of truth founded on evidence, and the same rejection of probabilism.

It is in the context of this debate with Cartesians that we must view Foucher's critical reading of Carneades' probabilism. ${ }^{23}$ While Cicero seems to have granted an enviable epistemological status to the probable, Foucher considers it as no more than a makeshift which ought not to constitute an essential component of Academic philosophy, since that philosophy ultimately aims at the true and the certain

21 Foucher, Dissertation, 125: "The Academics having admitted that the things we know begin from our ways of being [ideas], they assume that the first things we know belong to us and are in our souls, that is, in the being that knows within us."

22 Foucher, Dissertation, 144: "It is this that led Saint Augustine to say that if the Gospel had been preached at the time of these philosophers, they would have said, 'This is what we were looking for.' As well, we have had the experience of Platonists and Academics having willingly embraced our religion, so true is it that this disposition of mind which leads to contempt for sensory things and to avoiding prejudices is beneficial to Christianity."

23 Section 10 of the Dissertation (Ce que c'est que connaître les choses probablement, suivant les Académiciens; "What probable knowledge consists of, according to the Academics") is entirely dedicated to an exposition of the concept of the probable. See Foucher, 144-47. 
and to this end possesses a sure criterion, none other than evidence. According to Foucher, who again follows Descartes, it is evidence that provides that highly sought-after criterion of truth, while probability always contains an immanent reason for doubt:

Nous ne saurions trouver une meilleure marque de la vérité que la force qu'elle a d'emporter notre consentement malgré nous-mêmes, et sans que nous ajoutions quoi que ce soit à son action. Au lieu que la vraisemblance nous peut bien solliciter à consentir, mais elle ne saurait nous obliger de le faire malgré nous. ${ }^{24}$

In that case, a distinction must be made between the apodictic (or demonstrative) sciences such as mathematics-in which the probable plays no more than a methodological role and must bow out in favour of the demonstration to which it has given rise, whose evidence imposes itself on our minds-and hypothetical "sciences" such as medicine and moral philosophy, in which the probable finds justification because it allows for the desired action to occur but without our necessarily being able to know whether any better action could have occurred. Thus, according to Foucher, we must distinguish opinion-that is, the fact of acquiescing in things that are not evident and are at best probable, which means that opinion always includes a component of prejudice and is thus doubtful-from sensation, which consists of acquiescing in things that are clear and evident. Foucher reminds us that in matters of science, the wise person must assent only to the true and never to the probable, for assent to the probable is only tolerated in the sphere of the practical in order to avoid inaction and the reproach of apraxia levelled by the dogmatists.

This is why our knowledge is at one and the same time certain and limited, in contrast to divine knowledge; and it is in this respect that Cartesianism represents the height of philosophical arrogance, for it treats extension as the very substance of the material world, whereas for Foucher, although it is clear that we know the sensible world through our ideas, it is not obvious that the modifications of our immaterial soul are capable of representing a material thing. We are dealing here with one of the major issues of Foucher's epistemology, according to which the perceived world is no more than a relative one, ${ }^{25}$ of which science provides us with no more

24 Simon Foucher, Critique de la Recherche de la vérité (Paris: Martin Coustelier, 1675), 98: «We cannot find a better mark of the truth than the force with which it impels our consent in spite of ourselves and without our adding anything whatever to its action. Whereas, the probable can very well invite us to consent, but it cannot force us to consent in spite of ourselves.»

25 On this score, see the fictional dialogue between an Academic and a dogmatic presented in Foucher, Dissertation, 100: "It is not just with regard to a stick that appears to us to be bent in the water that our senses deceive us, it is with regard to everything we see in any setting whatever.' 'What?' he [the dogmatic] said, displaying astonishment, 'we only see phantoms?' 'If by that you mean that we only see the images of things that are outside of ourselves and not the things themselves, that is certain, because the senses only acquaint us with the effects and results of the action of external things. But these effects and results are no more than ways of being or modifications of 
than a summary description. ${ }^{26}$ Thus Foucher advances a "fallibilist" conception of science, because he deems that scientific propositions can be considered true so long as we manage to show that any other explanations for the same phenomena are false. In this way, progress is possible in science so long as we are in agreement about both the fact that scientific claims are revocable and the fact that they are not of the same order as the truths proper to the apodictic sciences. This scientific method, whose discovery, according to Foucher, is to be credited to the Academics, has the advantage of avoiding dogmatism and Pyrrhonism at the same time, as for Foucher, Pyrrhonism is a form of negative dogmatism.

\section{Jacques-Pierre Brissot de Warville: from Universal Scepticism to Revolutionary Dogmatism}

My third and final point deals with the radical differences between the reinterpretation of scepticism specific to the seventeenth century and the use made of it in the eighteenth century, in a context where Cartesianism and Christianity were both in crisis and no longer served as unconquered philosophical and theological reference points as in the previous century.

In these circumstances, the legacy of scepticism once more took on new shape and the sceptical texts of Antiquity ceased to serve primarily for the condemnation of the dogmatic arrogance of rationalist metaphysics, even though thinkers such as Voltaire continued to use them occasionally for this purpose. ${ }^{27}$ Rather, those texts were consulted primarily for their methodological value. Losing part of its critical radicality, scepticism now became a preparatory stage in which doubt was used to question current knowledge not in order to refute it but to deepen it. All of this harmonised with the concept of scientific progress established at that time. Of course, an ongoing increase in knowledge does not imply the disappearance of sceptical doubts. Indeed, doubt retains all its validity when a philosopher seeks to extrapolate from facts given by experience a metaphysics that would try to explain them within a system. Hence is the distinction made by the French thinkers of the Enlightenment between the "systematic mind" (esprit systématique), which is only concerned with classifying and ordering facts and discoveries, and the "spirit of the system" (esprit de système), which claims to be able to give them a final and ul-

our own substance, which depend on a large number of circumstances. It is not at all by the senses that we can judge of the realities of things, by the senses we can judge only of how they appear; and it is impossible that things should truly be everything they seem to be."

26 Which does not, of course, preclude the progress of science and an increasingly nuanced description of nature, as Foucher testifies when he mentions the progress achieved through the use of the microscope.

27 On Voltaire and scepticism, see Sébastien Charles, "Entre pyrrhonisme et académisme : le scepticisme de Voltaire," Cahiers Voltaire 11 (2012): 109-31. 
timate explanation. But if sceptical doubt is useful at a methodological level, the fact remains that the progress of science is undeniable and makes incongruous a radical and global form of scepticism, in which the idea of truth would be problematic. Hence Enlightenment thinkers often invoked a mitigated scepticism or reasonable Pyrrhonism, ${ }^{28}$ whose sphere of application must be restricted to the moral and political fields. This reasonable or mitigated scepticism, as it was then called, consists in making use of humility in the scientific domain and therefore has a methodological function. Moreover, it is strongly limited in its scope, touching only the field of natural philosophy, and leaving aside moral and political philosophy, not to mention religion.

On this score, the figure of Jacques-Pierre Brissot de Warville will now serve me well, for Brissot's case is one of a transition from radical scepticism to reasonable scepticism condensed into a period of just a few years. In this perspective, the reading proposed by Popkin, which renders Brissot an "optimistic sceptic"29 is highly questionable. To achieve this, Popkin would have to erase the subtle variations that led Brissot away from sceptical withdrawal to political engagement and assume that the young Brissot-who draped himself in the mantle of scepticism at the end of the 1770s-shared the convictions of the Brissot of ten years later, who wished to fulfil political ambitions. To assert, as Popkin does explicitly, ${ }^{30}$ that if Brissot did not complete his project of universal scepticism it was because he was so tragically cut down in 1793, is to overlook a large portion of Brissot's intellectual journey and to miss the fact that right from 1782, with the publication of his work on truth, his sceptical project had already been somewhat compromised.

It is true that in his early writings, Brissot is among the few eighteenth-century authors who present themselves as disciples of Sextus Empiricus, borrowing from Sextus the idea of a systematic critique of the sciences and applying it to the modern sciences for demonstrating both their vacuity and their uncertainty. In so doing, Brissot went against the tenor of a century that congratulated itself on the continuous progress of knowledge and the dissemination of the Enlightenment spirit.

\footnotetext{
28 Beausobre used this expression in 1755 in his Pyrrhonisme raisonnable (Berlin: Étienne de Bourdeaux, 1755). On this interpretation of scepticism, see Sébastien Charles, "Des excès dogmatiques à la guérison sceptique : le pyrrhonisme raisonnable de Beausobre," Libertinage et philosophie au XVII siècle 12 (2010): 205-17.

29 Richard H. Popkin, "Scepticism and Optimism in the Late 18th Century," in Aufklarüng und Skepsis. Studien zur Philosophie und Geistesgeschichte der 17. und 18. Jahrunderts, ed. Lothar Kreimendahl (Stuttgart: Fromman Verlag, 1995), 173-84.

30 Popkin, "Scepticism and Optimism," 176: "At the very end of his treatise, Brissot said that he hoped to discover in each science the very few truths that there are. He thought it would take him several years to do so. Then, in a footnote at the end, he said that if his work on legislation and politics permit, in two or three years he could present a 'tableau' of these truths along with a universal scepticism applied to all the sciences, and this would constitute a reasonable scepticism. Unfortunately Brissot was executed before he could complete his work because he was the leader of the Girondists."
} 
The first delineation of his monumental undertaking to undermine the scientific optimism of the Enlightenment is found in a manuscript Brissot referred to as Plan du scepticisme universel appliqué à toutes les sciences ("Plan for Applying Universal Scepticism to All the Sciences”). ${ }^{31}$ In this manuscript, which outlines a project conceived by the young Brissot as a collective enterprise that would offer readers a sceptical encyclopaedia to compete with Diderot and d'Alembert's Encyclopédie, Brissot's reflections take the form of a critical review of all the knowledge of his time:

Ressusciter le pyrrhonisme trop longtemps oublié, détruire les fondements de toutes les connaissances humaines, étendre le doute jusque sur les sciences qui semblent le plus évidemment marquées du sceau de la certitude, paraîtra le projet le plus fou, le plus ridicule, le plus atroce aux yeux des philosophes, des savants, des théologiens, des femmes même, qui tous se flattent de savoir quelque chose. On croit en effet dans ce siècle décoré du titre fastueux de philosophique, que l'homme a perfectionné toutes les sciences, parcouru tous les degrés de leur échelle; on croit que les erreurs ont disparu, que la vérité n'a plus de voile, on croit être au milieu de la lumière et on est toujours dans les ténèbres. ${ }^{32}$

The radicalism of Brissot's project resides above all in his rejection of certainty in the sphere of science, in which every discovery gives rise to new difficulties and adds to what is unknown, indeed unknowable. Passing from theology to metaphysics to other fields of thought, he uses and reuses the method of diaphonia, assuming that the clash between philosophical factions on every issue refutes dogmatism.

According to Popkin, Brissot's thought constitutes "the most extended presentation of French Enlightenment scepticism," 33 and we are indebted to him for having "carried scepticism beyond the usual moderate view of the preceding philosophers and scientists of the Enlightenment." ${ }^{34}$ But isn't this too optimistic? Brissot's radical scepticism is in evidence only in his unpublished manuscript on universal scepti-

31 See Jacques-Pierre Brissot de Warville, De la vérité, ou Méditations sur les moyens de parvenir à la vérité dans toutes les connaissances humaines (Neuchâtel: Imprimerie de la Société typographique, 1782), 361. The title Brissot uses there for the manuscript was the one he finally settled on; another title, Plan raisonné du système de pyrrhonisme général ("Reasoned Plan for a System of General Pyrrhonism"), is found on the manuscript itself, but struck out (See Brissot de Warville, Plan raisonné $d u$ système de pyrrhonisme général, Paris, Archives Nationales, pressmark 446 AP 21).

32 Brissot, Plan raisonné, f. 1. English translation: «To revive Pyrrhonism, too long forgotten, to destroy the foundations of all human knowledge, to extend the reach of doubt to include those sciences that seem to have been most clearly stamped with the seal of certainty, will appear to be the most foolish, ridiculous, and outrageous of projects in the eyes of philosophers, learned people, theologians, and even women, who all flatter themselves that they know something. It is the case that in this century, so lavishly styled 'philosophical,' it is believed that human beings have brought to completion all the sciences and climbed every rung of their ladders. It is believed that error has vanished, that truth is no longer obscured by a veil; it is believed that we are bathed in light even as we continue to dwell in darkness.» All English translations of Brissot de Warville are my own.

33 Popkin, "Scepticism and Optimism," 176.

34 Richard H. Popkin, "Brissot and Condorcet: Skeptical Philosophers," in The Skeptical Tradition around 1800, eds. Johan van der Zande and Richard H. Popkin (Dordrecht: Kluwer, 1998), 31. 
cism. The true project of his treatise on truth published in 1782 was no longer to demonstrate the vanity of the scientific enterprise, but rather to "seek what is certain in human knowledge." 35 Brissot had now embraced the "reasonable scepticism" of his century, which consisted at the theoretical level of developing a pragmatic concept of science and at the moral level of giving an ethical purpose, namely, human happiness, to the philosophical enterprise. ${ }^{36}$ Moreover, he expressed his hopes of establishing an organ intended to disseminate scientists' and scholars' observations in order to increase and perfect human knowledge, a project he followed up on in 1783, when he established, in London, both a "Lyceum," whose mission was to bring together scholars and scientists, and a journal designed to publish their discoveries.

Brissot's later thinking acknowledges that obstacles of course lie in the path of the search for truth and always will: the fallibility of the senses; confused and obscure ideas proper to certain fields such as metaphysics; the difficulty of grasping all the relationships that come together to produce a fact; the limits of the human mind; the misuse of words, especially abstract terms; the systematising spirit; false erudition; passions and prejudices. These are all factors that lead us to a recognition of the highly limited nature of the truths we can arrive at. But for all that, they do not invalidate this enterprise of making us wise and happy. From this perspective, philosophical inquiry should no longer seek to doubt for doubt's sake, but should aim to meditate in order to be useful to others and to one's self. For this reason scepticism is to be condemned, since it turns philosophy away from the consideration of the public good.

I think the interest of Brissot's case resides in the way he allows us to picture the transformation of the role of the philosopher at the end of the Enlightenment, which prefigures the intellectuel engagé of the last century and renders the sceptical posture, if not impossible, at least extremely rare. Of this transformation, Brissot was himself conscious, emphasising in his autobiographical sketch that he "wanted to liberate philosophy from the yoke of despotism." ${ }^{37}$ But being an activist for equality and liberty is to acknowledge value in ideals, which ancient sceptics taught to be irrational. Thus Brissot appears to have understood that the reactivation of scepticism in the eighteenth century presumed its readjustment and that the scepticism of the Enlightenment could not be independent of the new imperative of public utility which the philosopher must obey, therefore breaking with the Hellenistic ideal of the philosopher who is indifferent to the values shared in the public space.

35 Brissot, De la vérité, 1.

36 On the expressions "reasonable scepticism" and "mitigated Pyrrhonism" and their meaning, see Sébastien Charles, "Introduction," and Charles, "Escepticismo ilustrado: entre pirronismo razonable y escepticismo radical," in Dudas filosóficas. Ensayos sobre escepticismo antiguo, moderno y contemporáneo, eds. Armando Cintora and Jorge Ornelas (Barcelona: Editorial Genisa, 2014), 177-202.

37 Jacques-Pierre Brissot de Warville, "Portrait de Phédor," in Mémoires (1754-1793) (Paris: Alphonse Picard \& Fils, 1910), 1:15. 


\section{Conclusion}

The figures of Huet, Foucher, and Brissot illustrate well the plural uses made of scepticism in the seventeenth and eighteenth centuries, and the difficulty of providing a just interpretation of its nature and its function. Rather than trying to overestimate the importance of the Pyrrhonian current in relation to the Academic one, or to privilege the epistemic role played by scepticism in the question of the relationship between faith and reason, as Popkin did in his work, I wanted to show in this paper the difficulty of arriving at an unambiguous definition of the nature and function of early modern scepticism. It is thus difficult to define Huet's scepticism, be it Academic or Pyrrhonian, without taking into account the apologetic purpose of his work, where scepticism is an instrument used principally to serve the cause of Christianity. The same holds for Foucher, whose avowed purpose is identical, even if his use of scepticism follows a methodology ultimately very close to Cartesianism, which seems to him to make sceptics the best craftsmen of the development of early modern science. As for Brissot de Warville, his recourse to scepticism is just as dependent on a certain context, where scepticism is conceived primarily in a propaedeutic role, as a foundation for the natural philosophy of its time, which amounts to making him lose much of his radicality.

If I had malgré tout to give my definition of early modern scepticism, I would distinguish two forms. First, a radical form, dominant in the seventeenth century, which either employed sceptical arguments for religious purposes in order to save religion from rationalist criticism or, alternatively, employed sceptical arguments in order to question the principles on which religion is based (dogmas, miracles, prophecies, etc.). Second, a more mitigated form of scepticism, specific to the eighteenth century, which is mainly used as a method to overcome our prejudices and to build knowledge collectively according to the encyclopaedic model. In this respect, Hume's scepticism is an exception during the Enlightenment, as if the sceptical radicalism of the previous century was perpetuated through his thought. All this may appear very different from ancient scepticism, but it seems to me, nevertheless, that a certain spirit of scepticism has been preserved over time, which consists in thinking by oneself and distrusting dogmatism and prejudices, as if there were in fact a kind of skepsis perennis integrating both sides, Academic and Pyrrhonian. 


\section{Bibliography}

Beausobre, Louis de. Le pyrrhonisme raisonnable. Berlin: Étienne de Bourdeaux, 1755.

Boudreault, Joël and Sébastien Charles. "Simon Foucher's Academic Scepticism: Between Truth and Probability." In Academic Scepticism in the Development of Early Modern Philosophy, edited by Plinio Junqueira Smith and Sébastien Charles, 245-58. Dordrecht: Springer, 2017.

Brissot de Warville, Jacques-Pierre. De la vérité, ou Méditations sur les moyens de parvenir à la vérité dans toutes les connaissances humaines. Neuchâtel: Imprimerie de la Société typographique, 1782.

Brissot de Warville, Jacques-Pierre. Mémoires (1754-1793), Paris: Alphonse Picard and Fils, 1910.

Brissot de Warville, Jacques-Pierre. Plan raisonné du système de pyrrhonisme général. Paris, Archives Nationales, pressmark 446 AP 21.

Charles, Sébastien. "Des excès dogmatiques à la guérison sceptique: le pyrrhonisme raisonnable de Beausobre." Libertinage et philosophie au XVII siècle 12 (2010): 205-17.

Charles, Sébastien. "Entre pyrrhonisme et académisme : le scepticisme de Voltaire." Cahiers Voltaire 11 (2012): 109-31.

Charles, Sébastien. "Escepticismo Ilustrado: entre pirronismo razonable y escepticismo radical." In Dudas filosóficas. Ensayos sobre escepticismo antigo, moderno y contemporáneo, edited by Armando Cintora and Jorge Ornelas, 177-202. Barcelona: Editorial Genisa, 2014.

Charles, Sébastien. "Évidence, vraisemblance et vérité selon Huet : le cartésianisme en question." In Les usages de la preuve d'Henri Estienne à Jeremy Bentham, edited by Jean-Pierre Schandeler and Nathalie Vienne-Guerrin, 101-17. Paris: Hermann, 2014.

Charles, Sébastien. "Introduction: What is Enlightenment Scepticism? A Critical Rereading of Richard Popkin." In Scepticism in the Eighteenth Century: Enlightenment, Lumières, Aufklarüng, edited by Sébastien Charles and Plinio Junqueira Smith, 1-15. Dordrecht: Springer, 2013.

Charles, Sébastien. "On the Uses of Scepticism against a Certain Philosophical Arrogance: Huet as a Critic of Cartesian Logic and Metaphysics." Science et esprit 65, no. 3 (2013): 299-309.

Charles, Sébastien. "Pierre-Daniel Huet's Readings in Scepticism." In Academic Scepticism in the Development of Early Modern Philosophy, edited by Plinio Junqueira Smith and Sébastien Charles, 259-74. Dordrecht: Springer, 2017.

Foucher, Simon. Critique de la Recherche de la vérité. Paris: Martin Coustelier, 1675.

Foucher, Simon. Dissertation sur la recherche de la vérité. Paris: Estienne Michallet, 1687.

Foucher, Simon. Dissertations sur la recherche de la vérité, Paris: Jean Anisson, 1693.

Foucher, Simon. Nouvelle façon d'hygromètres. N.p.: 1672.

Foucher, Simon. Traité des hygromètres, ou machines pour mesurer la sécheresse et l'humidité de l'air. Paris: Estienne Michallet, 1686.

Giocanti, Sylvia. "Histoire du fidéisme, histoire du scepticisme." Revue de Synthèse 199, nos. 2-3 (April 1998): 193-210.

Huet, Pierre-Daniel. Against Cartesian Philosophy, edited and translated by Thomas M. Lennon. Amherst, New York: Humanity Books, 2003.

Huet, Pierre-Daniel. Alnetanae quaestiones de concordia rationis et fidei. Caen: J. Cavelier, 1690.

Huet, Pierre-Daniel. Censure de la philosophie de Descartes. Bibliothèque Nationale de France, manuscrit fonds français 14702.

Huet, Pierre-Daniel. Traité philosophique de la faiblesse de l'esprit humain. Amsterdam: Henri du Sauzet, 1723.

Lennon, Thomas M. "The Skepticism of Huet's Traité philosophique de la foiblesse de l'esprit humain." In Scepticisme et modernité, edited by Marc-André Bernier and Sébastien Charles, 65-75. Saint-Étienne: Publications de l'Université de Saint-Étienne, 2005. 
Maia Neto, José Raimundo. "Academic Skepticism in Early Modern Philosophy." Journal of the History of Ideas 58, no. 2 (1997): 199-220.

Maia Neto, José Raimundo. “Huet n'est pas un sceptique chrétien." Les Études philosophiques 2 (2008): 209-22.

Maia Neto, José Raimundo. "Huet sceptique cartésien.” Philosophiques 35, no. 1 (2008): 223-39.

Naya, Emmanuel. "Le phénomène pyrrhonien : lire le scepticisme au XVle siècle." PhD diss., Université Stendhal-Grenoble III, 2000.

Popkin, Richard H. "Brissot and Condorcet: Skeptical Philosophers." In The Skeptical Tradition around 1800, edited by Johan van der Zande and Richard H. Popkin, 31-39. Dordrecht: Kluwer, 1998.

Popkin, Richard H. The History of Scepticism from Savonarola to Bayle. Oxford: Oxford University Press, 2003.

Popkin, Richard H. "Scepticism and Optimism in the Late 18th Century." In Aufklarüng und Skepsis. Studien zur Philosophie und Geistesgeschichte der 17. und 18. Jahrunderts. Edited by Lothar Kreimendahl, 173-84. Stuttgart: Fromman Verlag, 1995.

Rapetti, Elena. Pierre-Daniel Huet: erudizione, filosofia, apologetica. Milan: Vita e Pensiero, 1999. 